
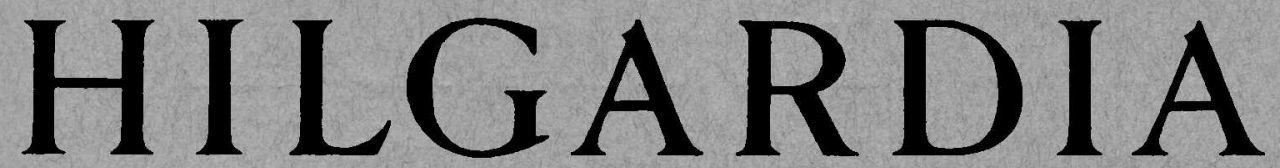

A Journal of Agricultural Science Published by the California Agricultural Experiment Station

\title{
PANSY LEAFSPOT, CAUSED BY CENTROSPORA ACERINA, HOST RANGE, AND CONTROL
}

C. M. TOMPKINS and H. N. HANSEN 
A serious leafspot disease of pansies and violas has been prevalent in the San Francisco Bay region since 1928. The disease develops only during the cold, wet, winter months. The causal organism has been identified as Centrospora acerina (Hartig) Newhall.

On pansy and viola leaves, small, blue-black, spherical to elliptical lesions, which may have a wet, greasy appearance on the lower side of the leaf, are found between, adjacent to, and on the veins and veinlets. Lesions also occur on petioles and inflorescences. Within a day or two after initial infection, the centers of the lesions may become necrotic, exhibiting a light to dark brown color, surrounded by a blue-black ring. Infected plants die promptly.

In the greenhouse, infection of pansies and violas was obtained by placing drops of a spore suspension from a pansy isolate on the upper surface of the leaves, atomizing with sterile distilled water, and covering the inoculated plants with glass jars. The incubation period ranged from 24 to $\mathbf{4 8}$ hours. Infected plants died within a week. The fungus was reisolated in pure culture, and the reisolates proved pathogenic.

In addition to pansy and viola, other ornamental bedding plants and vegetables were both naturally and artificially infected. Susceptible and nonsusceptible plants are listed.

The disease on pansy, viola, other susceptible ornamental bedding plants, French endive, narrow-leaf dandelion, and lettuce may be controlled by frequent spraying of the leaves during the rainy season with a copper oleate solution. Bedding plants listed as nonsusceptible may be grown in nurseries and outdoor plantings and require no spraying. 


\section{H I L G A R D I A}

A Journal of Agricultural Science Published by

the California Agricultural Experiment Station

VOL. 19

FEBRUARY, 1950

No. 12

\section{PANSY LEAFSPOT, CAUSED BY CENTROSPORA ACERINA, HOST RANGE, AND CONTROL'}

\section{M. TOMPKINS ${ }^{2}$ and H. N. HANSEN ${ }^{3}$}

\section{INTRODUCTION}

DuRING the wet, winter months of 1928-1929, a destructive leafspot disease of field-grown pansy (Viola tricolor L. var. hortensis DC.) and viola ( $V$. cornuta L.) plants, which had been propagated from seed, was observed simultaneously and apparently for the first time by several nurserymen and estate gardeners in San Francisco and San Mateo counties in California. Serious losses were incurred in that and in succeeding winter seasons; the crop was usually a total loss and could not be marketed. When a study of this disease was commenced in the winter of 1939-1940, combined annual losses to commercial pansy growers in these two counties had exceeded one million plants. In addition, uncounted thousands of plants were being destroyed annually in flats and baskets at retail nurseries, in the extensive out-of-doors plantings in cemeteries, in Golden Gate Park (San Francisco) and other smaller parks, and in home gardens. Further losses were being reflected in the infection, previously unreported in the literature, of other susceptible ornamental and vegetable plants.

In April, 1941, the disease occurred in epiphytotic form in flats of pansies and violas in an Oakland nursery. Although prevalent in succeeding years, the disease has been controlled by spraying with a suitable fungicide.

According to K. F. Baker, "the disease has not been found in southern California. This would seem to be consistent with the more northerly distribution of the fungus." 4

This paper deals with symptoms of the disease on pansy and other susceptible hosts found in California, and with control of the disease on certain of these hosts.

\section{REVIEW OF LITERATURE}

In the autumn of 1921 and 1922, according to Osterwalder (1924 a, b), , the leaves of young pansy plants grown in Switzerland developed conspicuous lesions. In a very limited inoculation test, he proved that infection was caused

\footnotetext{
${ }^{1}$ Received for publication August 12, 1949.

2 Associate Plant Pathologist in the Experiment Station.

${ }^{3}$ Professor of Plant Pathology and Plant Pathologist in the Experiment Station.

${ }^{4}$ Letter to Dean C. B. Hutchison, dated August 26, 1949.

"See "Literature Cited" for citations, referred to in text by author and date.
} 
within four days by a fungus which could not be identified with any of the existing species of Cercospora on account of its large spores. It was therefore named $C$. macrospora $\mathrm{n}$. sp. The only feasible control measure was thought to be the application of powdered calcium hydrate to the soil about two weeks before sowing the seed.

The pansy leafspot disease has been reported from Denmark (anonymous, 1929), and from Alaska (Wrangell), California, and Washington (Puyallup) by Newhall $(1944,1946)$. A culture of a pansy isolate of the fungus derived from infected plants grown in the San Francisco Bay region of California was sent by the writers to A. G. Newhall, Cornell University, Ithaca, New York in 1941 (Newhall, 1944).

The apparently limited host range of the fungus has been discussed by Westerdijk and Van Luijk (1924), Sprague (1937), Newhall (1941, 1944, 1946), Neergaard (1942), Truscott (1944), and Rader (1945).

With reference to the nomenclature of the fungus isolated from pansy and other hosts, Newhall (1944) was the first to change the name to Ansatospora macrospora (Osterw.) n. gen. Soon thereafter, Hansen and Tompkins (1945) published a note in which they referred to the earlier work of Hartig (1880) and proposed the binomial Ansatospora acerina (Hart.) n. comb. However, Newhall (1946) had meanwhile discovered a paper published during the war years by Neergaard (1942) in which the latter described a fungus on parsley roots, in Denmark, caused by Centrospora ohlsenii. Since the generic name took precedence over that suggested by Newhall (1944), he now proposed (Newhall, 1946) the present name of Centrospora acerina (Hartig) n. comb.

\section{SYMPTOMS OF THE DISEASE}

During cold, wet, windy weather in the winter season, leaves, petioles, and inflorescences of pansy plants become infected in less than 12 hours (plate 1). At first, all lesions are very small, ranging in size from mere flecks to one or two millimeters in diameter. Blue-black in color on the upper surface of the leaf (plate $1, \mathrm{~A}$ to $\mathrm{H}$ ), they assume a wet, greasy appearance on the lower surface. Distribution of the lesions, few to many in number, is more or less irregular and at random. They may be found between, adjacent to, or on the veins and veinlets (plate 1 ). Sometimes more lesions develop on one side of the midrib than on the other. They also occur commonly on petioles (plate 1, L). A day or two after infection, lesions may enlarge to five or more millimeters in diameter and develop a light tan center surrounded by a blue-black ring. The lesions tend to retain their individual identity, although with age some coalescence occurs. On older leaves, the tissues surrounding the lesions may become chlorotic, forming a light green halo. Lesions are roughly spherical to elliptical in shape. On inflorescences they are of the same general character (plate 1, I, J, K). Severe infection causes pansy plants to die within a few days. Whenever the disease develops in epiphytotic proportions, few if any plants escape infection.

The symptoms for pansy also apply in general to viola, all other susceptible ornamental bedding plants (naturally and experimentally infected), lettuce, narrow-leaf dandelion, and a few vegetable plants (experimentally infected). Dark brown lesions are formed at or near the crown on parsnip roots. 


\section{THE CAUSAL FUNGUS, CENTROSPORA ACERINA}

Isolations made from diseased pansy leaves, collected in Alameda, San Francisco, and San Mateo counties, on poured plates of potato-dextrose agar have consistently yielded a fungus which has been identified as Centrospora acerina (Hartig) Newhall (plate 2).

Healthy pansy and viola plants were grown in six-inch pots of autoclaved soil. When ready for inoculation, the pots were thoroughly watered.

Pure cultures of the organism were used in the infection experiments. Inoculum was prepared on poured plates of pea-straw agar which were incubated outside a north window to encourage sporulation (Snyder and Hansen, 1947). Because of the enormous size of the spores, averaging $160 \mu$ in length, preliminary infection tests showed that they failed to pass through the openings of a DeVilbiss atomizer. Consequently, the inoculation technique consisted of placing a drop or two of a previously prepared spore suspension on each leaf of the plant to be inoculated with a sterile pipette, then atomizing the leaves with sterile distilled water to insure the distribution of the spores over the surface. The inoculated plants were then covered with large glass tumblers or jars to provide the necessary humidity. All inoculation tests were conducted in a cold greenhouse, with daily air temperatures ranging from $13^{\circ}$ to $18^{\circ} \mathrm{C}$.

To establish proof of pathogenicity, 25 pansy plants, variety Steele's Jumbo, and 25 viola plants, variety Blue Perfection, were inoculated with spores from a pansy isolate. The same number of plants, their leaves atomized with sterile distilled water, served as controls. All inoculated plants showed symptoms of infection on leaves, petioles, and inflorescences within 24 hours, and severe infection after 48 hours (plate 3 ). They died within a week. The control plants remained healthy. The fungus was reisolated from each infected plant and the reisolates proved pathogenic. The symptoms on artificially infected plants were identical with those of naturally infected plants. Similar results were later obtained in testing other varieties of pansy, including Swiss Giants and Maple Leaf.

Successful reciprocal inoculations on celery and pansy with a celery isolate from A. G. Newhall of Cornell University and the California pansy isolate showed them to be identical.

In later infection tests conducted under unusually favorable environmental conditions in the greenhouse, i.e., a prolonged, cold period of rainy weather, pansy plants have shown severe symptoms 12 hours after inoculation.

\section{HOST RANGE}

In addition to pansy and viola, the following ornamental bedding plants have been found to be highly susceptible to natural infection by Centrospora acerina:

Canterbury bells (Campanula medium L.) (plate 4, D, E)

columbine (Aquilegia sp.)

Delphinium cultorum Voss

Petunia hybrida Vilm.

Ranunculus asiaticus $\mathrm{L}$.

Scabiosa atropurpurea $\mathrm{L}$. var. Blue Moon 
Lobelia hybrida Hort.

Chinese forget-me-not (Omphalodes linifolia Moench) (plate 4, A)

Pentstemon barbatus Nutt.

bachelor button or cornflower (Centaurea cyanus L.)

Diseased specimens of the above-listed ornamentals were collected in the field, and the fungus isolated from tissue plantings on potato-dextrose-agar poured plates in the laboratory. Healthy plants were grown from seeds in the greenhouse and were tested by inoculating the leaves, using the same technique employed in the infection experiments with pansy. All inoculated plants became infected, while the controls remained healthy.

Natural infection did not occur, nor were inoculations successful on the following ornamental bedding plants :

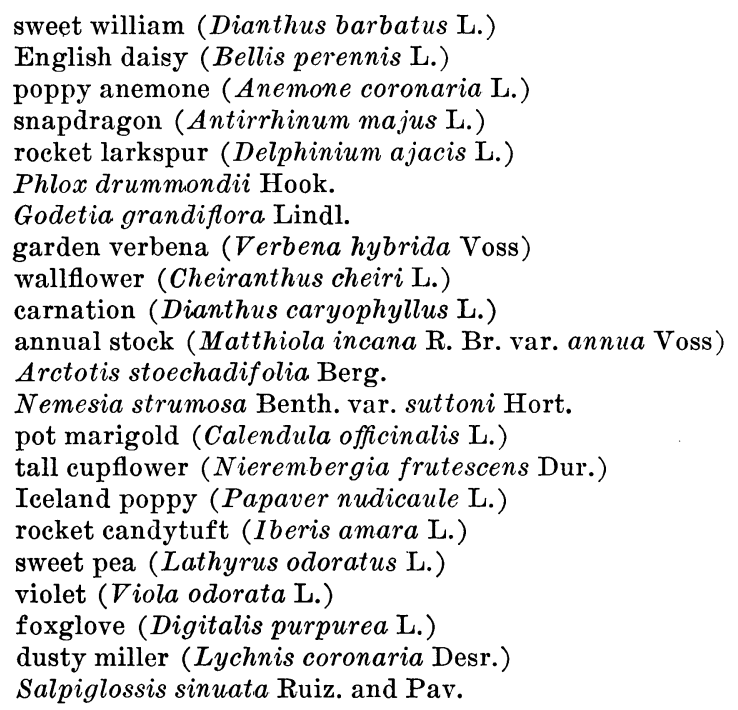

Seeds of all the ornamentals listed above were sown in flats in the greenhouse, and the young seedlings were transplanted into pots. When ready, they were inoculated by the method previously described. None became infected, which is in full agreement with field observations.

It is worthy of note that field-grown violet plants, a close relative of pansy and viola, appear to be immune to the disease.

The following vegetable plants are susceptible to natural infection:

French endive (Cichorium intybus L.)

lettuce (Lactuca sativa L. var. capitata Hort.) var. California butter or local, plate 5, A) narrow-leaf dandelion (Taraxacum officinale Weber) var. Calabrasa (plate 5, C, D. E) parsnip (Pastinaca sativa L.)

The disease was reproduced on seedling plants of lettuce and narrow-leaf dandelion in the greenhouse. French endive plants were not available for inoculation.

In 1944, the fungus was isolated from partially-decayed roots of parsnip plants grown at Colma. Ten healthy parsnip roots were inoculated, in sterile 
glass moist chambers lined with moist, sterilized filter paper, by placing a small block of agar inoculum on the unwounded surface and covering with sterile absorbent cotton previously dipped in sterile distilled water. The moist chambers were then transferred to a cool greenhouse. Infection was obtained in four days (plate 6, B, C) and the fungus was reisolated in pure culture. The reisolates proved pathogenic. The four control roots remained healthy (plate 6, A). A pansy isolate of the fungus also proved pathogenic on parsnip roots.

Like pansies and violas, all ornamental bedding and vegetable plants, naturally infected, were always a total loss to the growers. The symptoms on the various susceptible plants were essentially of the same pattern as those occurring on pansy and viola, with one exception. Parsnip plants showed no leaf infection; the damage was confined to the taproots.

In greenhouse tests, leaves of the following ornamental plants were artificially infected :

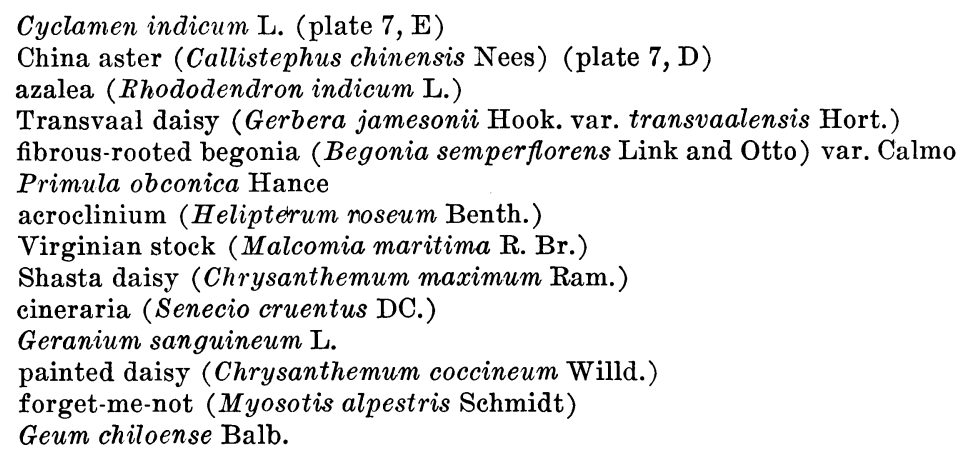

Also, the following vegetable plants were experimentally infected in the greenhouse :

spinach (Spinacia oleracea L.) var. Bloomsdale (plate 7, A)

peas (Pisum sativum L.) (plate 7, C)

horsebean (Vicia faba L.) (plate 7, B)

caraway (Carum carvi) (plate 8)

cabbage (Brassica oleracea L. var. capitata L.) var. Winter Colma

celery (Apium graveolens L.) var. Golden Self Blanching

eauliflower (Brassica oleracea L. var. botrytis L.) var. February

Chinese cabbage (Brassica chinensis L.) var. Gai Choi

tomato (Lycopersicum esculentum Mill. var. vulgare Bailey) var. Early Santa Clara

bean (Phaseolus vulgaris L.) var. Perfection

Canner

carrot (Daucus carota $\mathrm{L}$.) var. Chantenay

lettuce (Lactuca sativa L. var. romana Hort.) var. Romaine parsley (Petroselinum hortense Hoffm.)

\section{CONTROL OF THE DISEASE ON PANSIES AND OTHER ORNAMENTAL AND VEGETABLE HOSTS}

Soon after discovery of the disease on pansy and other ornamental bedding plants, control experiments were initiated. The early tests were based on drenching the plant beds with a 2 per cent formaldehyde solution and covering with wet sacks for two days. After two weeks, the beds were seeded with 
pansies. The young pansy plants were heavily infected during the early part of the winter season.

Two copper oleate materials (Greenol and Mil-Du-Spra ${ }^{6}$ ) were next applied to the foliage of the plants at a concentration of 1 to 800 . These spray materials, consisting of a copper salt in an oleaginous base, leave no noticeable residue on the leaves after application, thus conforming to a highly essential requirement for fungicides used on ornamental bedding plants. Excellent control was obtained, while unsprayed, adjoining plots became infected. Growers immediately adopted a spray program based on the use of these materials, and over a period of years they have continued to give good control of the disease on pansies and other susceptible ornamentals. These fungicides, relatively inexpensive, are applied immediately after a rain, or between rains, and are necessary only during the rainy season. Usually no further natural infection occurs after May 1 with the commencement of the dry season.

Excellent control of the disease was also obtained on field plantings of head lettuce and narrow-leaf dandelion with each of these fungicides.

The selection of nonsusceptible bedding plants would, of course, obviate the need of sprays in nurseries and other outdoor plantings.

\section{DISCUSSION}

In the San Francisco Bay region, pansies and violas, longtime favorite ornamental bedding plants because of their attractive flowers, are grown extensively in nurseries during the winter months, finding a ready market for transplanting in parks, cemeteries, estates, and home gardens. For best growth they require sandy loam soil, abundant moisture, and relatively low air temperatures.

During the period 1928-1939 their production and use were seriously curtailed due to epiphytotics of a leafspot disease which spread with great rapidity during the rainy season, and not infrequently caused complete failure of the crop.

According to Newhall (1946) the pansy disease was found at Wrangell, Alaska, on September 3, 1934, by K. F. Gravatt. It was later reported from a commercial planting of pansies at Puyallup, Washington, in the spring of 1945. Records on the occurrence of the pansy disease in California apparently antedate all others in North America.

Although the disease on pansy was first described by Osterwalder (1924 a, b) in Switzerland, his papers were largely mycological in nature. Only fragmentary information was given on symptoms, illustrated by one sketch of an infected leaf, and control, while host range was not mentioned. Because of the lack of essential data, it seemed advisable to make a thorough study of the disease, with particular reference to symptoms, host range, and control. As a result of these studies, pansies and violas can now be grown with comparative safety during the normal season, and with little or no annual loss.

\footnotetext{
${ }^{6}$ Greenol is manufactured by California Spray Chemical Corporation, Richmond, California; Mil-Du-Spra by Shell Oil Company, San Francisco, California.
} 


\section{LITERATURE CITED}

\section{Anonymous.}

1929. Plantesygdomme i Danmark 1928. Oversigt, samlet ved Statens plantepatologiske Fors $\emptyset$ g. Tidsskr. Planteavl. 35:420-471.

Hansen, H. N., and C. M. Tompkins.

1945. The name of Ansatospora macrospora. Phytopathology 35:218-220.

HARTIG, ROBERT.

1880. Der Ahornkeimlingspilz Cercospora acerina M. Untersuch. Forstbot. Inst. München 1:58-62.

NegrgaArd, Paul.

1942. Mykologische Notizen II. Zentbl. f. Bakt., Parasit., u. Infekt. (II) 104:407-412.

Newhall, A. G.

1941. An undescribed storage rot of celery. (Abstract) Phytopathology 31:17.

1944. A serious storage rot of celery caused by the fungus Ansatospora macrospora $\mathrm{n}$. gen. Phytopathology 34:92-105.

1946. More on the name Ansatospora acerina. Phytopathology 36:893-896.

OSTERWALDER, A.

1924a. Ueber die durch Cercospora macrospora Osterw. verursachte Blattkrankheit bei den Pensées. Mitt. Thurgauische Naturf. Gesells. 25:59-80.

1924b. Bericht der schweizerischen Versuchsanstalt für Obst-, Wein- und Gartenbau im Wädenswil für die Jahre 1921-1923. IV. A. 6. Ueber die durch Cercospora macrospora verursachte Blattkrankheit an Pensées. Landw. Jahrb. der Schweiz. 38:616617.

RADER, WM. E.

1945. Ansatospora acerina found causing decay of stored carrots in Wayne County, New York. Plant Disease Reporter 29:522.

SNyder, William C., and H. N. HÁnsen.

1947. Advantages of natural media and environments in the culture of fungi. Phytopathology 37:420-421.

SPRAGUe, RODERICK.

1937. New or noteworthy parasitic species of fungi imperfecti in Oregon. Mycologia $29: 426-433$.

TruscotT, J. H. L.

1944. A storage rot of celery caused by Ansatospora macrospora (Osterw.) Newhall. Canadian Journal Research (C) $22: 290-304$.

WesterdiJK, Johanna, and A. VAN LUIJK.

1924. Eine Anthraknose des Kümmels (Carum carvi). Meded. Phytopath. Lab. 'Willie Commelin Scholten,' Baarn 8:51-54. 


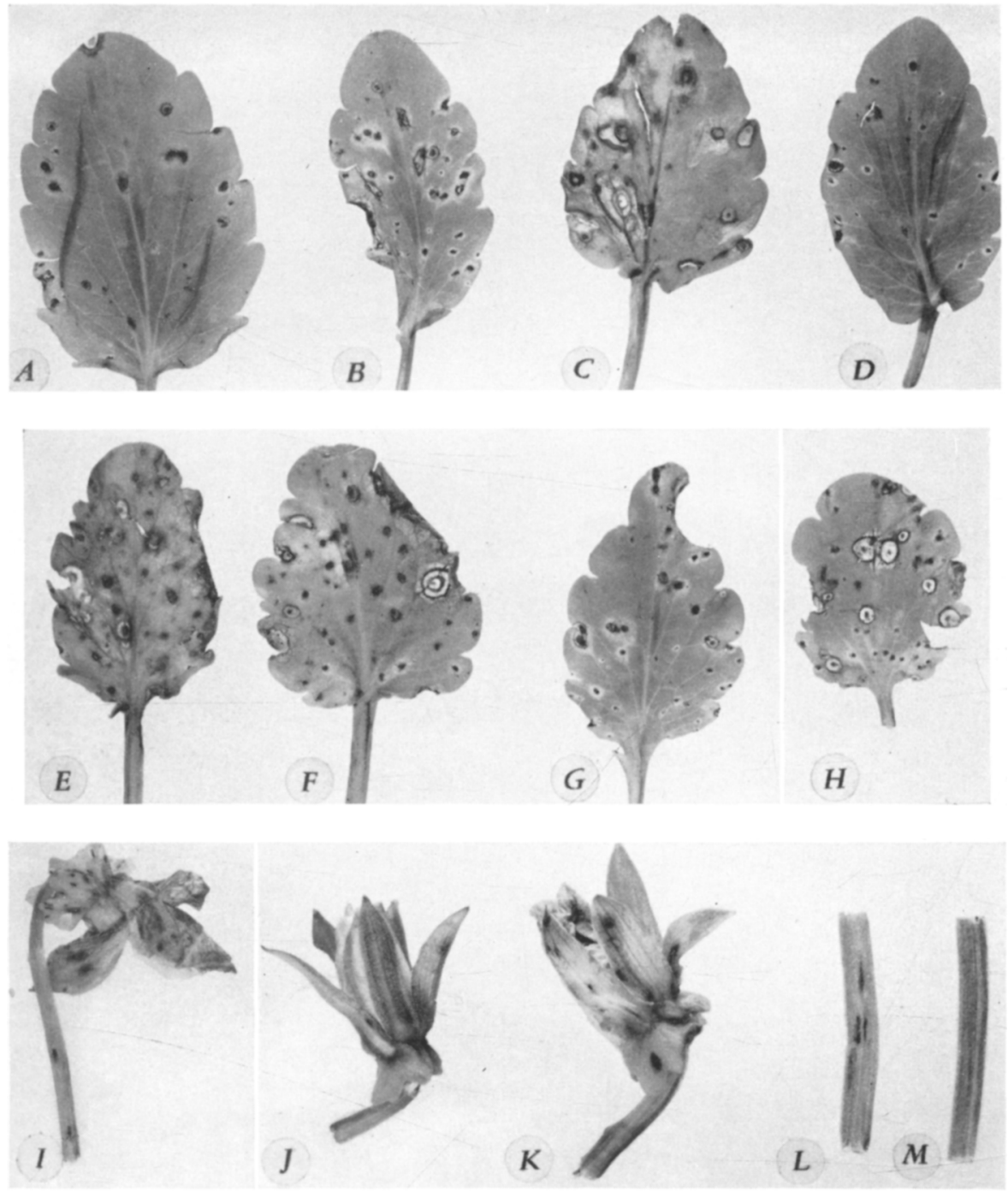

Plate 1. Symptoms of pansy leafspot induced under natural conditions by the fungus, Centrospora acerina: A to $\mathrm{H}$, typical blue-black lesions, 1 to $5 \mathrm{~mm}$. in diameter, spherical to elliptical in shape, in some cases with necrotic brown centers, occurring between, adjacent to, and on the veins and veinlets, with some coalescence; I, J, K, lesions on inflorescences; L, lesions on petiole; M, healthy petiole. 


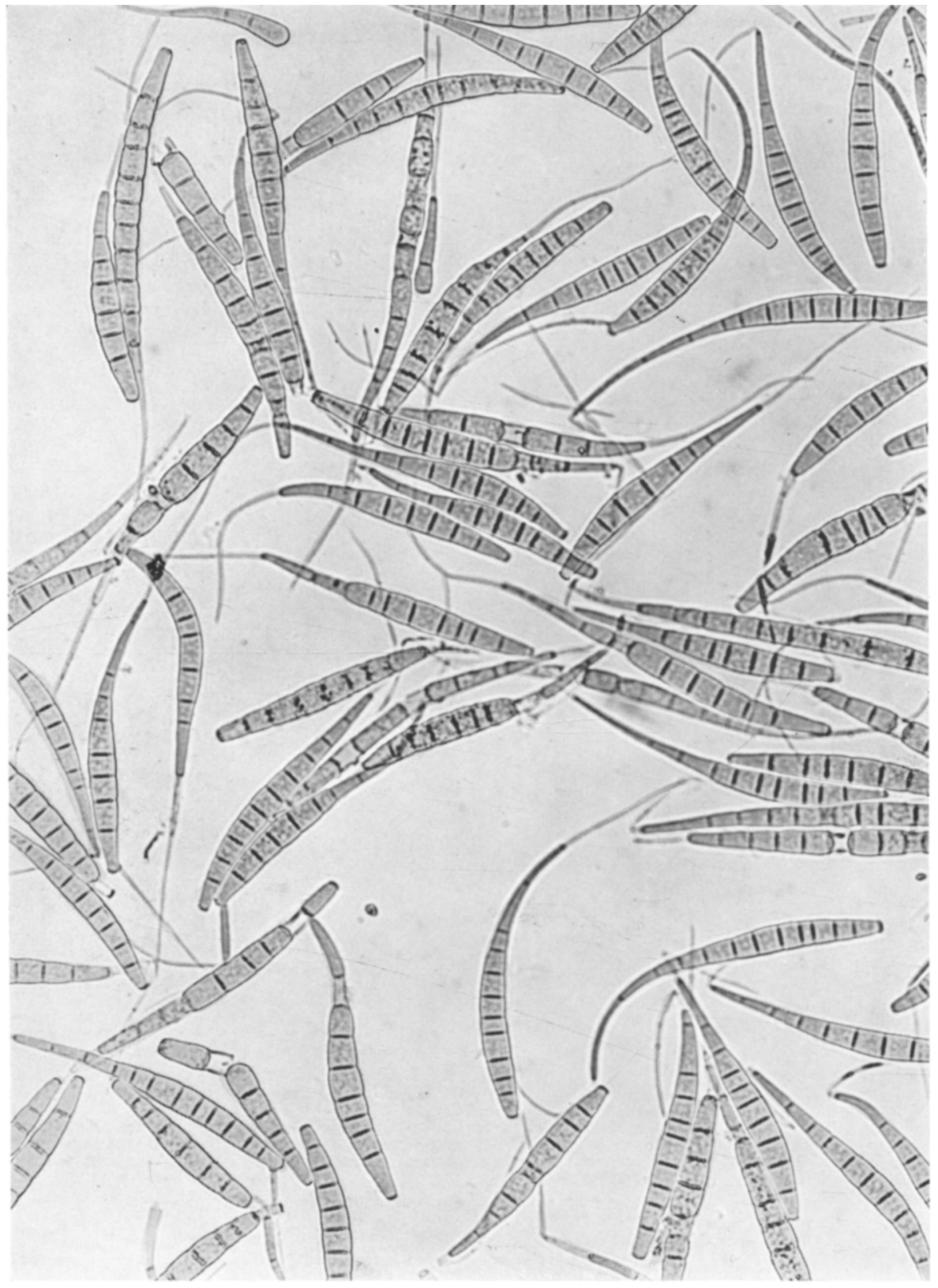

Plate 2. Typical spores of Centrospora acerina developed in a pure culture of an isolate from pansy. $x 250$. 

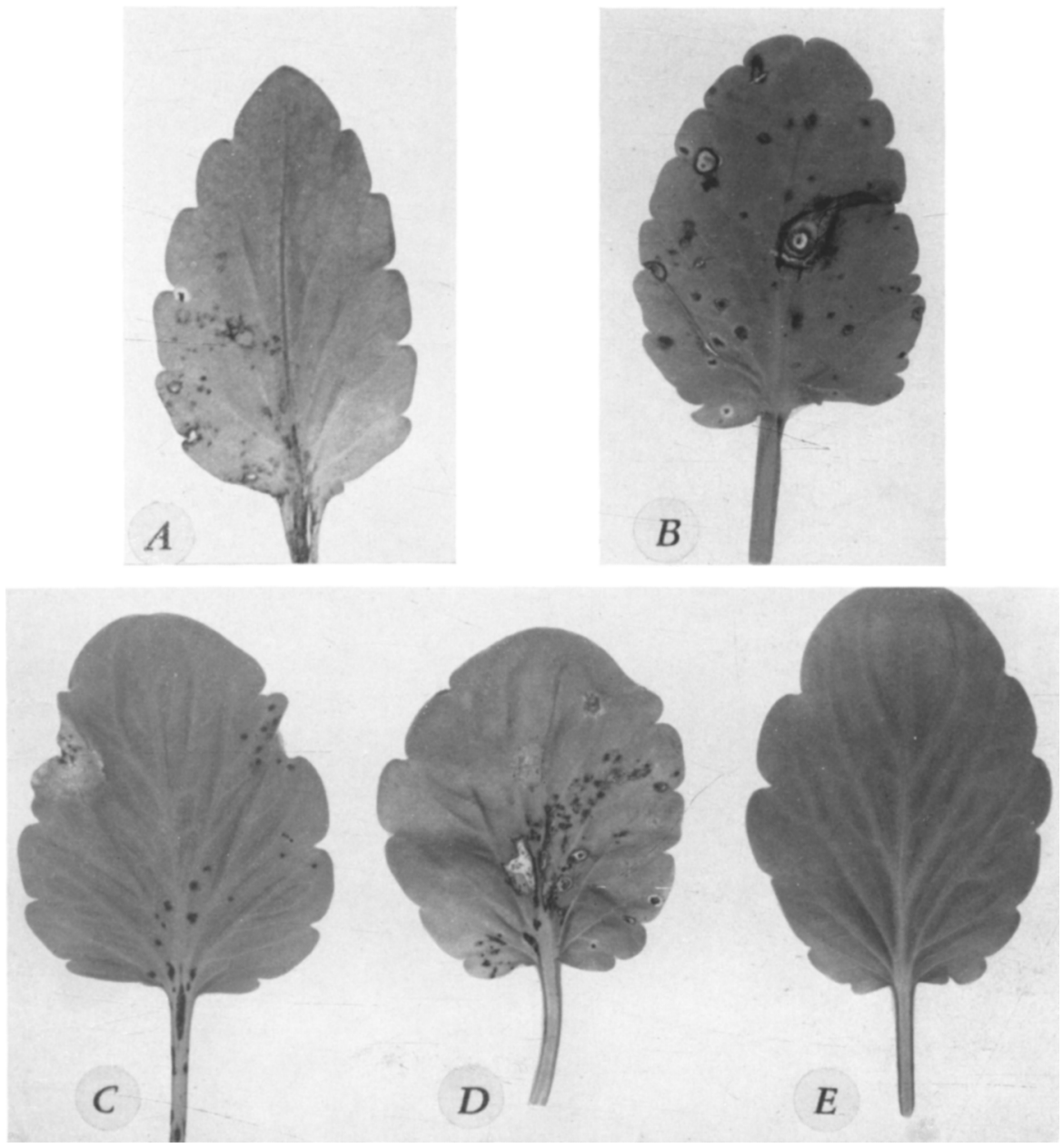

Plate 3. Symptoms of pansy leafspot induced by artificial inoculation with the fungus, Centrospora acerina, in the greenhouse at air temperatures of $13^{\circ}$ to $18^{\circ} \mathrm{C}$. (within 24 hours): $\mathrm{A}, \mathrm{B}, \mathrm{C}, \mathrm{D}$, typical blue-black lesions on leaf blades and petioles, showing some coalescence of lesions; $\mathrm{E}$, healthy pansy leaf. 


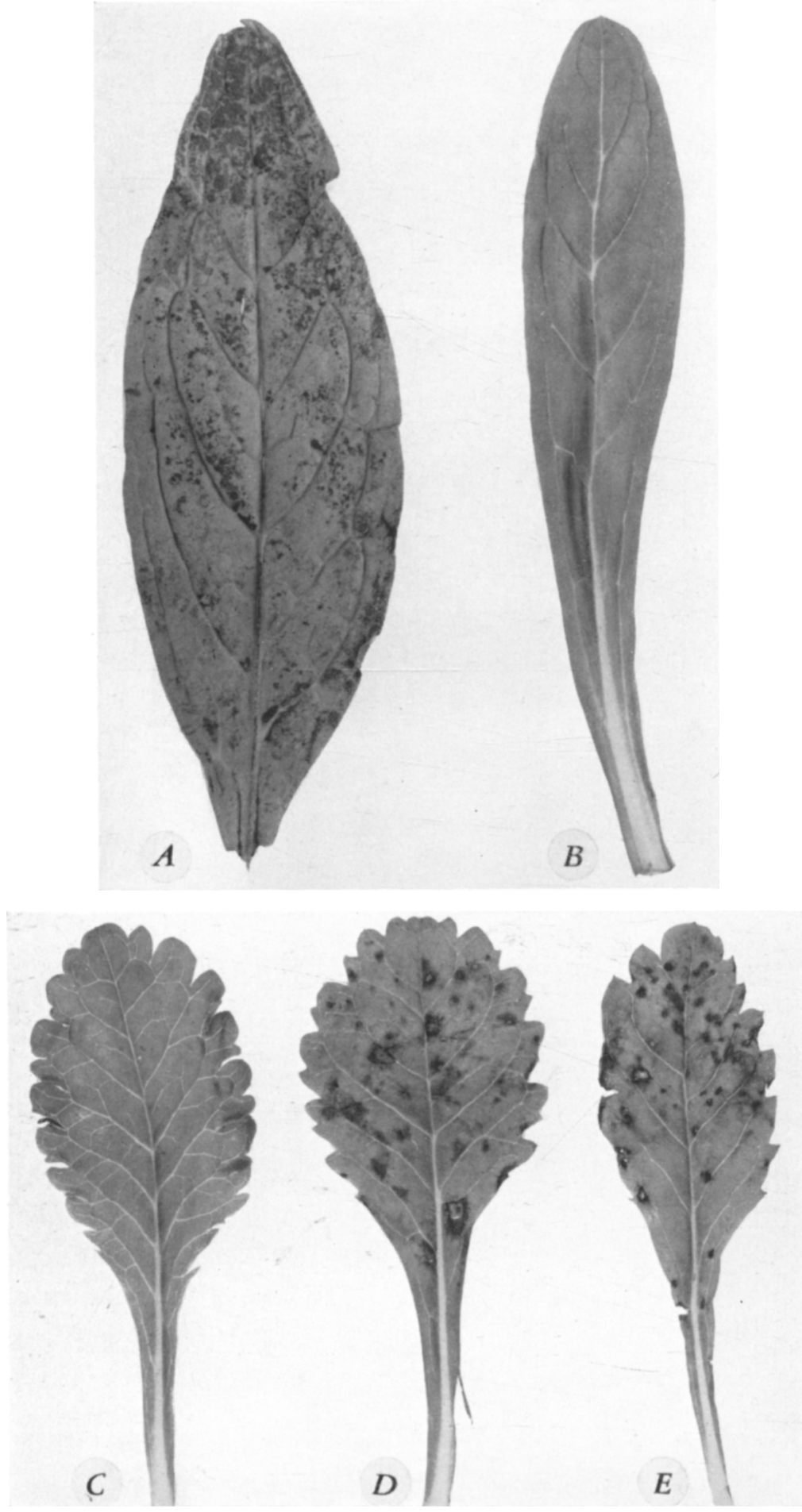

Plate 4. Symptoms induced on certain ornamental hosts under natural conditions by the fungus, Centrospora acerina: A, typical lesions on leaf of Chinese forget-me-not; $B$, healthy leaf of Chinese forget-me-not; C, healthy leaf of Canterbury bells; D, E, infected leaves of Canterbury bells. 

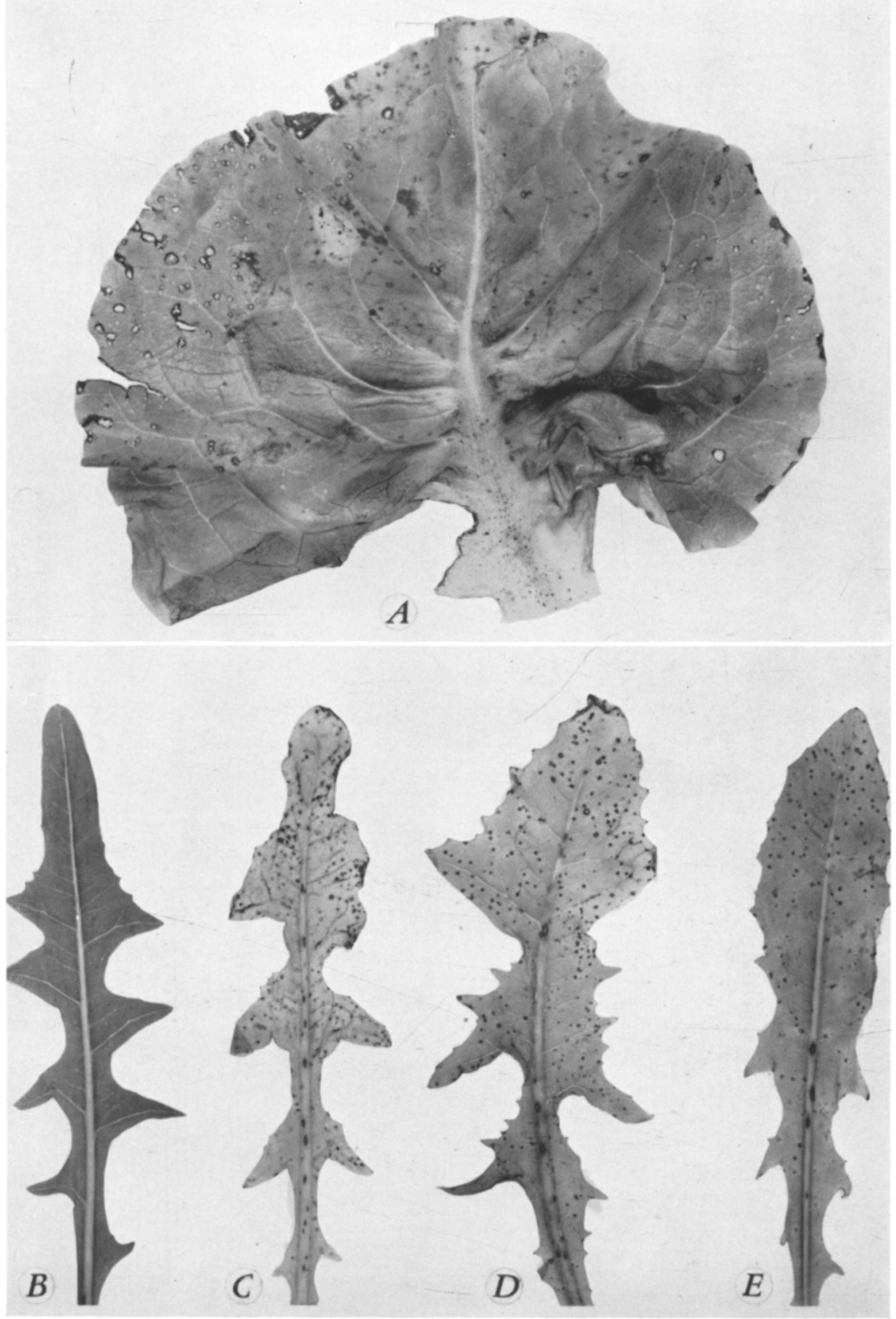

Plate 5. Symptoms induced on certain vegetable hosts under natural conditions by the fungus, Centrospora acerina: A, infected leaf of California butter or local lettuce; B, healthy leaf of narrow leaf dandelion; C, D, E, infected leaves of narrow-leaf dandelion. 

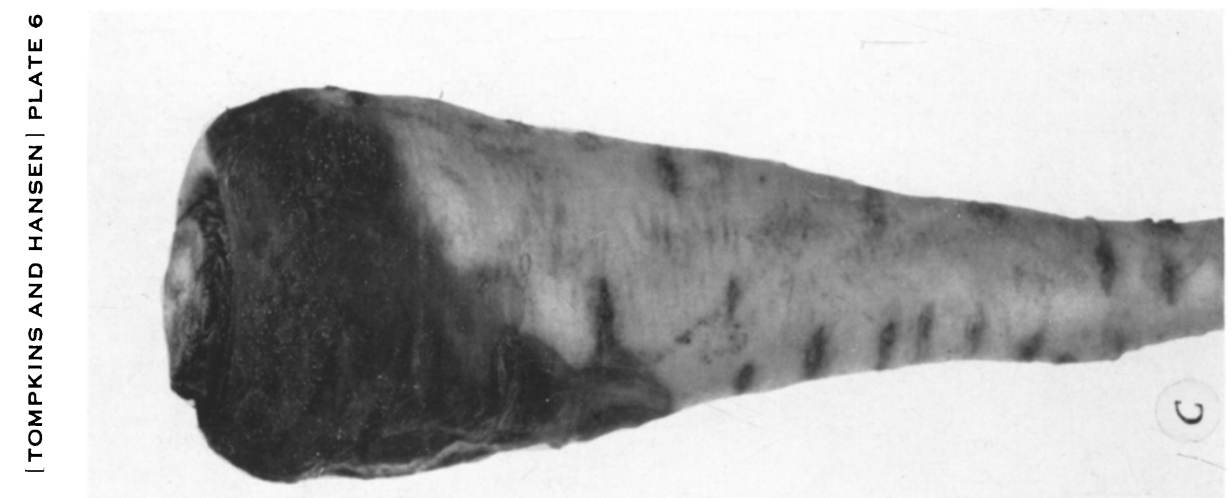

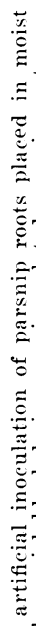

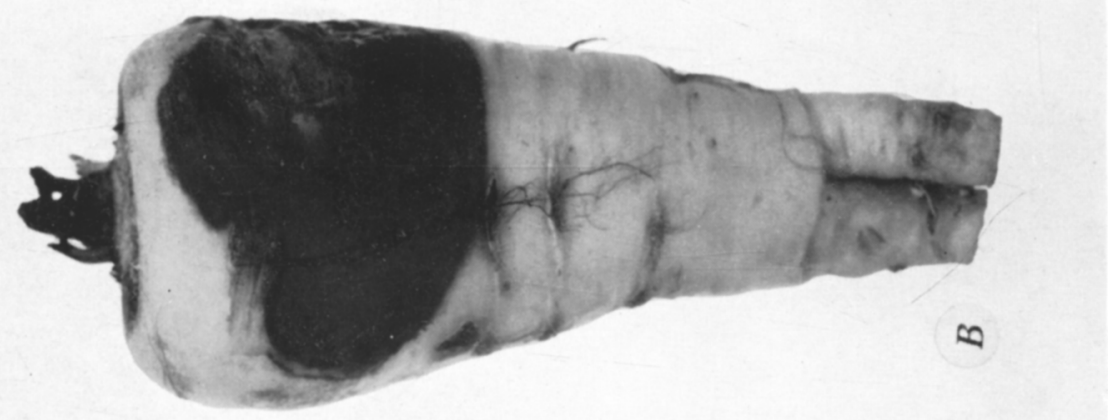

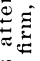

政

$\exists$

Eั

.

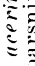

政

菅

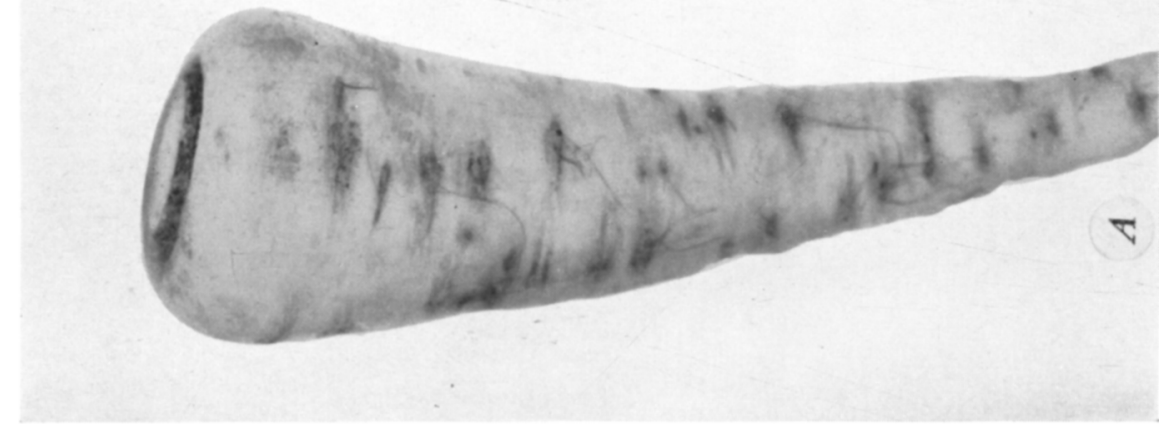

풍

ב.

跣

影

范 


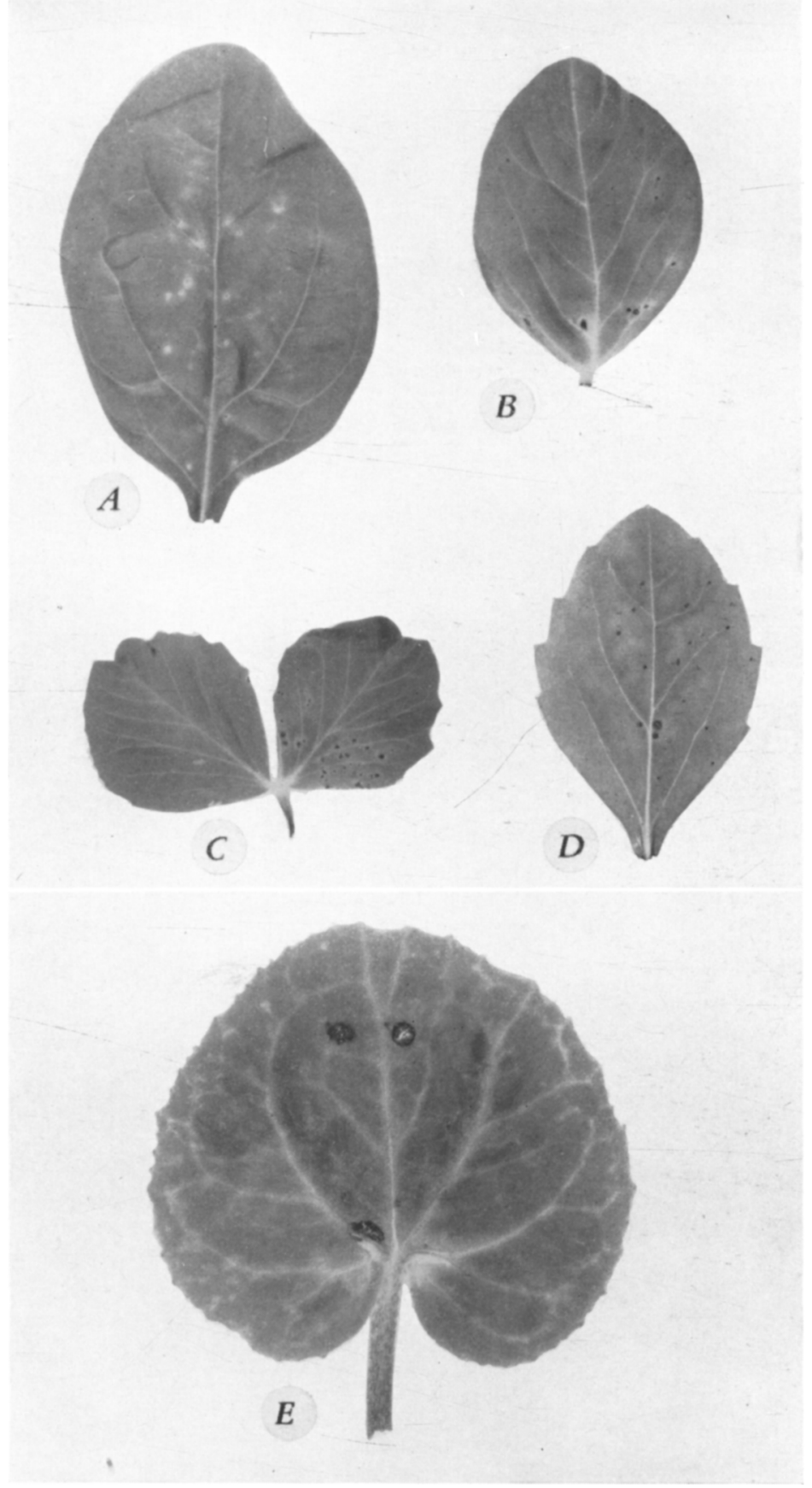

Plate 7. Symptoms induced on the leaves of certain vegetable and ornamental plants by artificial inoculation with the fungus, Centrospora acerina, in the greenhouse: A, spinach; B, horsebean; C, peas; D, China aster; E, cyclamen. After 48 hours. 


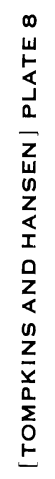
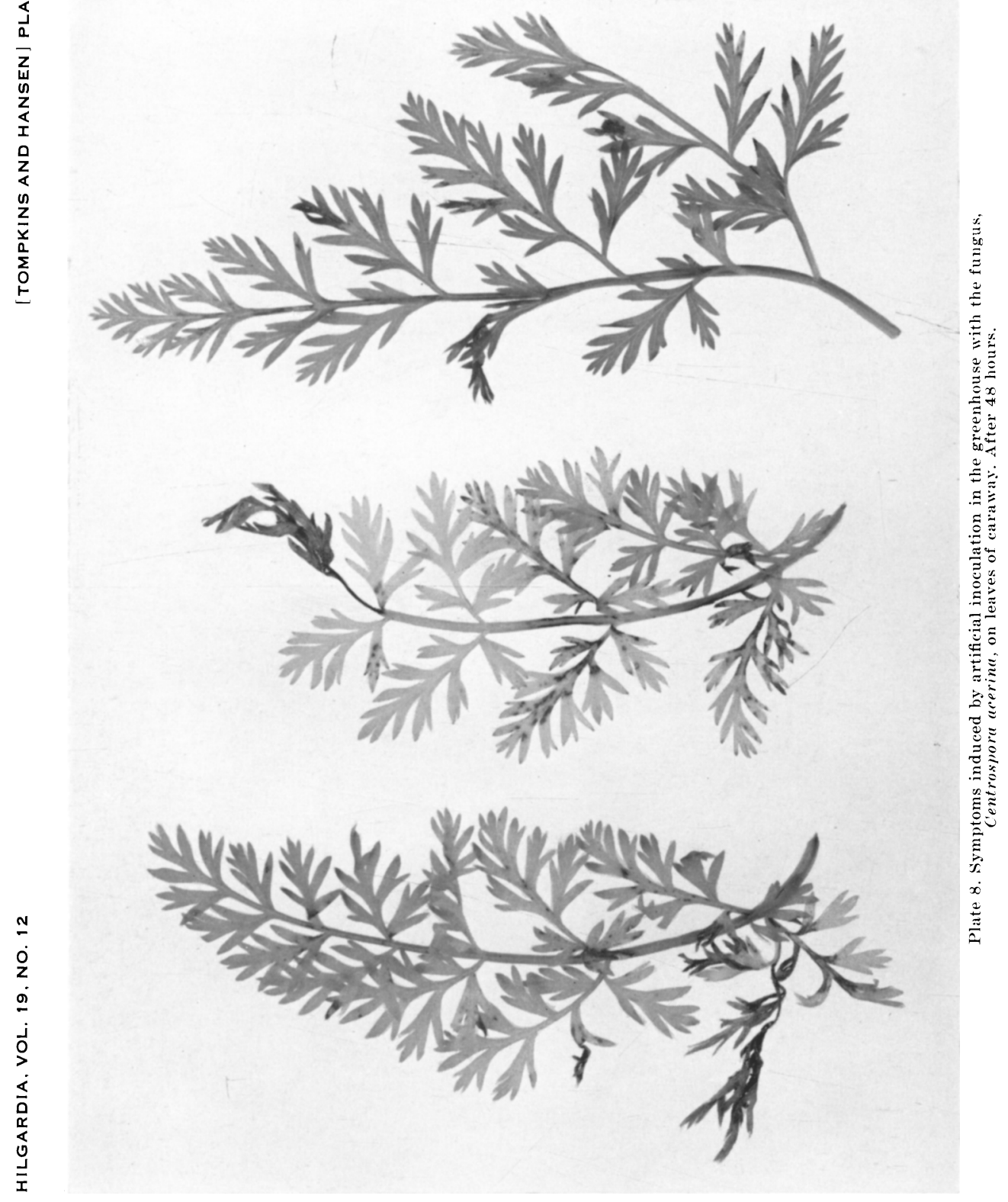
The journal Hilgardia is published at irregular intervals, in volumes of about 600 pages. The number of issues per volume varies.

Subscriptions are not sold. The periodical is sent as published only to libraries, or to institutions in foreign countries having publications to offer in exchange.

You may obtain a single copy of any issue free, as long as the supply lasts; please request by volume and issue number from:

\section{Publications Office \\ College of Agriculture \\ Berkeley 4, California}

The limit to nonresidents of California is 10 separate issues on a single order. A list of the issues still available will be sent on request.

In order that the information in our publications may be more intelligible, it is sometimes necessary to use trade names of products or equipment rather than complicated descriptive or chemical identifications. In so doing, it is unavoidable in some cases that similar products which are on the market under other trade names may not be cited. No endorsement of named products is intended nor is criticism implied of similar products which are not mentioned. 